\title{
Electrodeposition of Protocrystalline Germanium from Supercritical Difluoromethane
}

\author{
Charlie Y. Cummings, ${ }^{\mathrm{a} \dagger}$ Philip N. Bartlett, ${ }^{\mathrm{a}^{*}}$ David Pugh, ${ }^{\mathrm{a}}$ Gillian Reid, ${ }^{\mathrm{a}}$ William
} Levason, ${ }^{a}$ Mahboba M. Hasan, ${ }^{\text {a }}$ Andrew L. Hector, ${ }^{a}$ Joe Spencer, ${ }^{b}$ David C. Smith, ${ }^{b}$ Samuel Marks, ${ }^{\mathrm{c}}$ Richard Beanland ${ }^{\mathrm{c}}$

${ }^{a}$ Chemistry, University of Southampton, Southampton, SO17 1BJ, UK

${ }^{b}$ Physics and Astronomy, University of Southampton, Southampton, SO17 1BJ, UK

${ }^{c}$ Department of Physics, University of Warwick, Coventry, CV4 7AL, UK

†Present address: Department of Chemical Engineering and Biotechnology, Tennis Court Road, Cambridge, CB2 1TQ, UK

To be submitted to ChemElectroChem

Proofs to Prof P. Bartlett

p.n.bartlett@soton.ac.uk 


\begin{abstract}
We report results for the electrochemistry of the germanium(II) trihalide anions, $\left[\mathrm{GeCl}_{3}\right]^{-},\left[\mathrm{GeBr}_{3}\right]^{-}$and $\left[\mathrm{GeI}_{3}\right]^{-}$, in supercritical difluoromethane containing $60 \mathrm{mM}$ $\left[\mathrm{N}^{n} \mathrm{Bu}_{4}\right]\left[\mathrm{BF}_{4}\right]$ at $19.1 \mathrm{MPa}$ at $358 \mathrm{~K}$. The voltammetry shows mass transport limited currents for reduction to germanium at gold on the first scan. There is no evidence for a germanium stripping peak and on subsequent scans the electrode slowly passivates with the deposition of around $\sim 0.4 \mu \mathrm{m}$ of material. The redox potentials for reduction of the three trihalides are in the order $\left[\mathrm{GeCl}_{3}\right]^{-}<\left[\mathrm{GeBr}_{3}\right]^{-}<\left[\mathrm{GeI}_{3}\right]^{-}$with the iodide being the most easily reduced complex. Electrodeposition of germanium onto TiN electrodes from supercritical difluoromethane at $19.1 \mathrm{MPa}$ at $358 \mathrm{~K}$ using either 16 $\mathrm{mM}[\mathrm{EMIM}]\left[\mathrm{GeI}_{3}\right]$ with $60 \mathrm{mM}[\mathrm{EMIM}]\left[\mathrm{BF}_{4}\right]$ or $16 \mathrm{mM}\left[\mathrm{N}^{n} \mathrm{Bu}_{4}\right]\left[\mathrm{GeI}_{3}\right]$ with $60 \mathrm{mM}$ $\left[\mathrm{N}^{n} \mathrm{Bu}_{4}\right]\left[\mathrm{BF}_{4}\right]$ gave deposition rates of 2 to $3 \mu \mathrm{m} \mathrm{h}^{-1}$. Raman spectroscopy and transmission electron microscopy showed that the resulting germanium films were protocrystalline, containing nanocrystals of germanium embedded in an amorphous germanium matrix.
\end{abstract}

Keywords: difluoromethane, germanium, protocrystalline, supercritical fluid electrodeposition, germanium(II) tri-iodide. 


\section{Introduction}

Germanium and germanium-based materials are of high technological interest in advanced applications from optics, ${ }^{[1]}$ to high speed electronics, ${ }^{[2]} \mathrm{Li}$-ion batteries, ${ }^{[3]}$ and third generation photovoltaics. ${ }^{[4]}$ Germanium is a Group IV semiconductor with chemistry similar to that of silicon. ${ }^{[5]}$ Despite this, the microelectronic industry favours silicon as the material of choice due to the stability of its oxide and compatibility with commercial fabrication systems. ${ }^{[6]}$ However, there has been a resurgence in interest in thin film or nanostructured germanium and these materials are usually formed using conventional vacuum processes such as chemical vapour deposition $^{[7]}$ or molecular beam epitaxy. ${ }^{[8]}$

Electrodeposition of germanium has a long history. ${ }^{[9]}$ Early work by Szekely, ${ }^{[10]}$ subsequently taken up by others, ${ }^{[11]}$ used $\mathrm{GeCl}_{4}$ in propylene carbonate, despite the fact that $\mathrm{GeCl}_{4}$ is a moisture sensitive liquid at room temperature. This method has been used for deposition of quite large areas in waveguides ${ }^{[1 \mathrm{~b}-\mathrm{d}]}$ and most recently in work by IBM. ${ }^{[11 \mathrm{a}, 11 \mathrm{~h}]}$ The most detailed characterisation of the deposits appears to be by Saitou et al. ${ }^{[11 \mathrm{~g}]}$ There are also reports of the use of zintl ions, $\left[\mathrm{Ge}_{9}\right]^{4-}$, in ethylene diamine $^{[12]}$ and of deposition from water. ${ }^{[13]}$ Deposition from water generally leads to films which are ultra-thin. Thus Stickney's group has worked on ECALE (ElectroChemical Atomic Layer Epitaxy) and ways to deposit Ge from aqueous solution $^{[13 \mathrm{~b}, 13 \mathrm{c}]}$ and Maldonado's group have described studies of Ge deposition on $\mathrm{Au}$ from $\mathrm{GeO}_{2}$ in water. ${ }^{[13 \mathrm{a}]}$ Their SERS studies showed that $\mathrm{H}$ terminated Ge thin films convert to glassy oxide after 30 minutes in air.

Progress in the use of ionic liquids as solvents for electrochemistry has also driven interest in germanium electrodeposition. In particular Endres' group has been active in this area since 2000. ${ }^{[14]}$ In their early work they used $\mathrm{GeCl}_{4}, \mathrm{GeBr}_{4}$ and $\mathrm{GeI}_{4}$ in 
$[\mathrm{BMIM}] \mathrm{PF}_{6}{ }^{[14-15]}(\mathrm{BMIM}=1$-butyl-3-methylimidazolium). Their later work shifts to other ionic liquids without $\left[\mathrm{PF}_{6}\right]^{-}$, which causes problems. ${ }^{[16]}$ Endres' work includes deposition of Ge photonic crystals using colloidal templates ${ }^{[16 k, 17]}$ and deposition of Ge nanowires (90 nm diameter, 1-2.5 microns long) using track etch membranes. ${ }^{[16 \mathrm{c} \text {, }}$ 16d] Their work on germanium deposition from $\mathrm{GeCl}_{4}{ }^{[18]}$ has been followed up by others.

In the work of both Endres ${ }^{[14-15,15 \mathrm{~d}-\mathrm{f}]}$ and Fransaer, ${ }^{[19]}$ despite the ionic liquids having the advantages of extending the potential window for deposition and removing impurities (such as water), deposition of germanium still suffers from selftermination, with films growing at a retarded rate. Approaches to overcome this, including raising the temperature of the electrolyte and introducing a metal additive $^{[19 a]}$ have been investigated. For example, recent work by Fransaer's group used germanium deposition from $\mathrm{GeCl}_{4}$ in 1-butyl-1-methyl pyrrolidinium bis(trifluoromethylsulfonyl)imide $\left([\mathrm{BMP}]\left[\mathrm{Tf}_{2} \mathrm{~N}\right]\right)$ at an elevated temperature $(>423 \mathrm{~K})$ in a sealed cell $\left(\sim 0.4 \mathrm{MPa}\right.$ to prevent evaporation of the $\left.\mathrm{GeCl}_{4}\right)$ to give a higher plating rate of $6.0 \mu \mathrm{m} \mathrm{hr}^{-1}{ }^{[19 \mathrm{~b}]}$

An alternative approach, first described by Maldonado's group, is the electrochemical liquid-liquid-solid (ecLLS) process,${ }^{[13 a, 20]}$ which in many ways is an electrochemical equivalent of the well-known vapour-liquid-solid (VLS) process. ${ }^{[21]}$ In this case germanium is electrodeposited into a liquid metal alloy and subsequently precipitated out at the point of saturation, forming films or nanowires. Of necessity the dopant level of the $\mathrm{Ge}$ is relativity high and hence limits these germanium nanowires for use in degenerate semiconductor devices; Mahenderkar and co-workers recently reported germanium nanowires with a $0.2 \%$ atom indium contamination using this type of ecLLS approach. ${ }^{[22]}$ 
In contrast to this work in liquid solvents, we have studied the electrodeposition of germanium from supercritical fluids. ${ }^{[23]}$ The motivation for this is the absence of surface tension in the supercritical state, coupled with the relatively high mass transport rates and elevated deposition temperature: factors that make supercritical fluid electrodeposition attractive for the deposition into extreme (sub $20 \mathrm{~nm}$ ) nanostructures and templates for device applications. ${ }^{[24]}$ In our original work we demonstrated the deposition of germanium thin films from both $\left[\mathrm{N}^{n} \mathrm{Bu}_{4}\right]\left[\mathrm{GeCl}_{3}\right]$ and $\mathrm{GeCl}_{4}$ in supercritical $\mathrm{CO}_{2} / \mathrm{MeCN}$ and in supercritical difluoromethane $\left(\mathrm{scCH}_{2} \mathrm{~F}_{2}\right)$, respectively. Deposits formed from $\mathrm{GeCl}_{4}$ in $\mathrm{scCH}_{2} \mathrm{~F}_{2}$ at a high over potential, were found to contain amorphous germanium with significant chloride contamination. Subsequently we studied deposition of germanium from $\left[\mathrm{N}^{n} \mathrm{Bu}_{4}\right]\left[\mathrm{GeCl}_{3}\right]$ in $\mathrm{scCH}_{2} \mathrm{~F}_{2}$ and reported an improvement in the quality of germanium thin films. ${ }^{[23 a]}$ The predominantly amorphous germanium films produced could be converted to the crystalline phase by a thermal post-deposition treatment. However, for these films the deposition rate was slow $\left(\sim 0.4 \mu \mathrm{m} \mathrm{hr}^{-1}\right)$.

In this paper we present the results of a study of the electrochemistry of the germanium(II) tri-halide anions, $\left[\mathrm{GeCl}_{3}\right]^{-},\left[\mathrm{GeBr}_{3}\right]^{-}$and $\left[\mathrm{GeI}_{3}\right]^{-}$in $\mathrm{scCH}_{2} \mathrm{~F}_{2}$. This was motivated by our earlier study of the electrochemistry of these species in dichloromethane, ${ }^{[25]}$ where it was found that the $\left[\mathrm{GeI}_{3}\right]^{-}$anion had the most positive reduction potential, well within the electrochemical window of the electrolyte, suggesting that it might be the best choice for germanium deposition. In this work we show that this is also true in $\mathrm{scCH}_{2} \mathrm{~F}_{2}$ and that germanium deposition from $\left[\mathrm{GeI}_{3}\right]^{-}$is approximately ten times faster than that from $\left[\mathrm{GeCl}_{3}\right]^{-}$. We report results for analysis of as-deposited films using scanning electron microscopy (SEM), Raman spectroscopy, X-ray diffraction (XRD) and transmission electron microscopy (TEM). 
We also show that the $\mathrm{Ge}$ deposits from $\left[\mathrm{GeI}_{3}\right]^{-}$in $\mathrm{scCH}_{2} \mathrm{~F}_{2}$ at $358 \mathrm{~K}$ are protocrystalline, that is they contain Ge nanocrystals dispersed in amorphous film of Ge ${ }^{[26]}$ as demonstrated by Raman spectroscopy and TEM.

\section{Results and Discussion}

\subsection{Voltammetry of [EMIM][GeCl$\left.]_{3}\right],[E M I M]\left[\mathrm{GeBr}_{3}\right]$ and [EMIM][GeI $\left.{ }_{3}\right]$ on $\mathrm{Au}$ electrodes in $\mathrm{scCH}_{2} \mathrm{~F}_{2}$}

In this work, where we compare the electrochemistry of the three Ge(II) halides, we have used $\left[\mathrm{BF}_{4}\right]^{-}$containing electrolytes. $\left[\mathrm{BF}_{4}\right]^{-}$is a very weakly coordinating anion, hence is unlikely to influence the speciation at the Ge(II) halide complex anions $\left[\mathrm{GeX}_{3}\right]^{-}(\mathrm{X}=\mathrm{Cl}, \mathrm{Br}$ and $\mathrm{I})$. In earlier work we have studied the phase behaviour and conductivity of solutions of $\left[\mathrm{N}^{n} \mathrm{Bu}_{4}\right]\left[\mathrm{BF}_{4}\right]$ in $\mathrm{scCH}_{2} \mathrm{~F}_{2}{ }^{[27]}$ This clearly showed that the system forms a single supercritical phase under the conditions used in the present work (358 $\mathrm{K}$ and 19.2 $\mathrm{MPa}$ ) and that the molar conductivity for the electrolyte is around $50 \mathrm{~S} \mathrm{~cm}^{2} \mathrm{~mol}^{-1}$ at $363 \mathrm{~K}$ and $22 \mathrm{MPa}$ for a $60 \mathrm{mM}$ solution of $\left[\mathrm{N}^{n} \mathrm{Bu}_{4}\right]\left[\mathrm{BF}_{4}\right]$. Figure 1A shows cyclic voltammetry on $\mathrm{Au}$ and TiN electrodes for the background electrolyte, $60 \mathrm{mM}\left[\mathrm{N}^{n} \mathrm{Bu}_{4}\right]\left[\mathrm{BF}_{4}\right]$, with either $16 \mathrm{mM}[\mathrm{EMIM}] \mathrm{I}$ or $16 \mathrm{mM}\left[\mathrm{NBu}^{n}{ }_{4}\right] \mathrm{I}$ added. Iodide is expected to have the smallest electrochemical window due to the ready onset of iodide oxidation (compared to either bromide or chloride oxidation) at anodic potentials. The onset of electrolyte reduction occurs at $E_{\text {onset }}=\sim-1.5 \mathrm{~V} v s$. $\mathrm{Ag} \mid \mathrm{LaF}_{3}$ for $\mathrm{Au}$ and $E_{\text {onset }} \approx-1.8 \mathrm{~V}$ vs. $\mathrm{Ag} \mid \mathrm{LaF}_{3}$ for $\mathrm{TiN}$. The uncompensated resistance for each electrode can be estimated from the slope of the voltammogram in the anodic limit taking account of the difference in electrode areas $\left(\mathrm{Au} \sim 0.002 \mathrm{~cm}^{2}\right.$, TiN $\sim 0.4 \mathrm{~cm}^{2}$ ). Using the known conductivity of the supercritical fluid electrolyte, ${ }^{[27]}$ 
$\sim 3 \mathrm{mS} \mathrm{cm}^{-1}$, and Newman's equation for the electrolyte resistance for a disc electrode,${ }^{[28]}$ we estimate the expected uncompensated resistance to be $\sim 3.3 \mathrm{k} \Omega$ for the Au electrode and $\sim 230 \Omega$ for the TiN electrode, in reasonable agreement with the experimental values of $2.6 \mathrm{k} \Omega$ and $162 \Omega$ respectively. We attribute the observed cathodic current to the reduction of the $\left[\mathrm{N}^{n} \mathrm{Bu}_{4}\right]^{+}$and $[\mathrm{EMIM}]^{+}$cations. However, the possibility of electrochemically forming a carbene in the $[\mathrm{EMIM}]^{+}$case cannot be ruled out. ${ }^{[29]}$
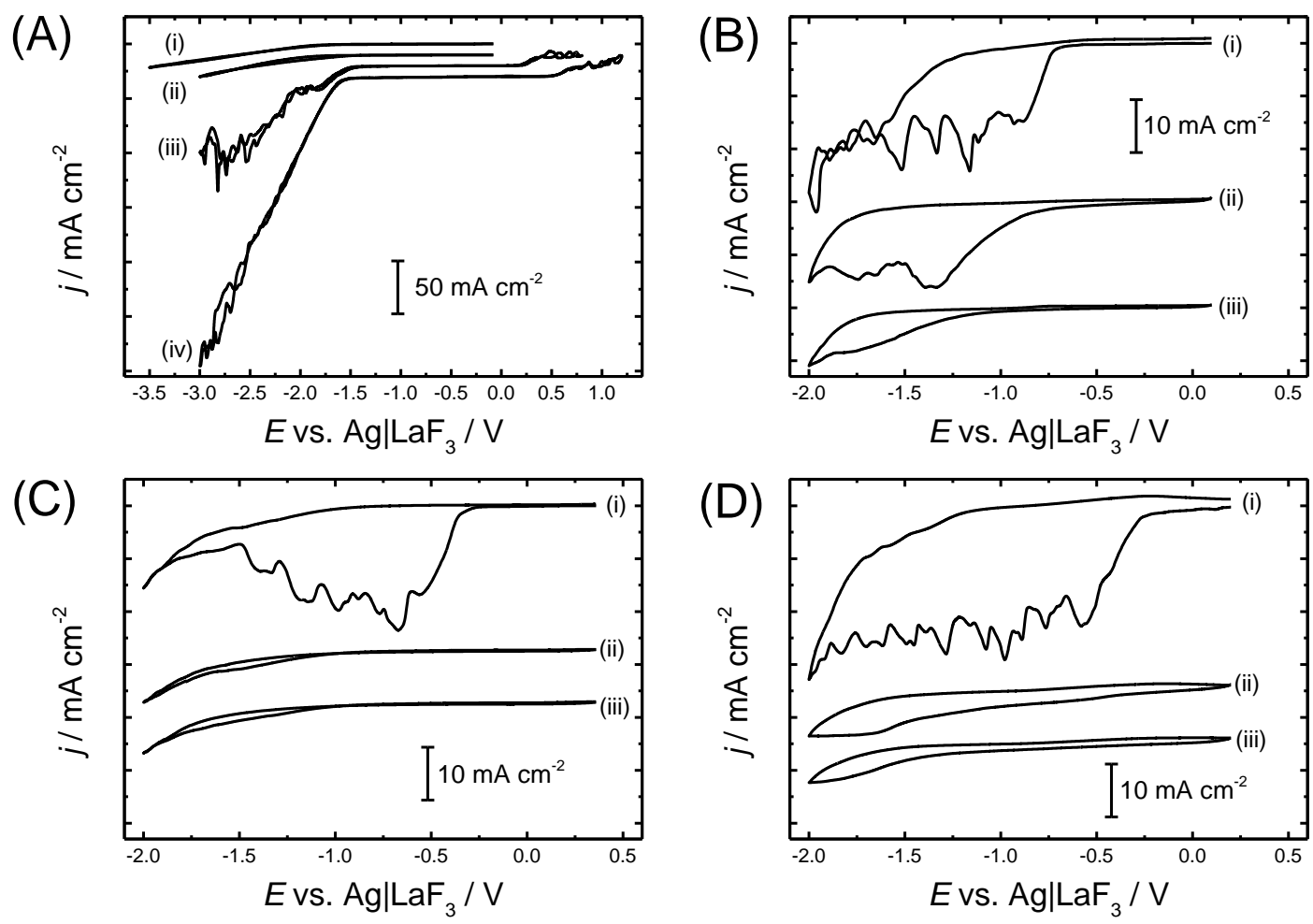

Figure 1: (A) Offset cyclic voltammograms of various electrodes in $\mathrm{scCH}_{2} \mathrm{~F}_{2}(358 \mathrm{~K}$, $19.3 \mathrm{MPa}$ ) with $60 \mathrm{mM}\left[\mathrm{N}^{n} \mathrm{Bu}_{4}\right]\left[\mathrm{BF}_{4}\right]$ as background electrolyte, $100 \mathrm{mV} \mathrm{s}^{-1}$ with (i)

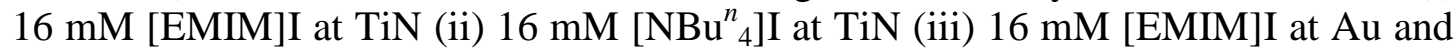
(iv) $16 \mathrm{mM}\left[\mathrm{N}^{n} \mathrm{Bu}_{4}\right] \mathrm{I}$ at $\mathrm{Au}$. (B) Consecutive cyclic voltammograms of an $\mathrm{Au}$ disc electrode in $11 \mathrm{mM}$ [EMIM] $\left[\mathrm{GeCl}_{3}\right]$, (i) $1^{\text {st }}$ (ii) $2^{\text {nd }}$ (iii) $3^{\text {rd }}$ scans. (C) Consecutive cyclic voltammograms of an Au disc electrode in $13 \mathrm{mM}$ [EMIM] [GeBr 3$]$, (i) $1^{\text {st }}$ (ii) $2^{\text {nd }}$ (iii) $3^{\text {rd }}$ scans. (D) Consecutive cyclic voltammograms of an Au disc electrode in $16 \mathrm{mM}[\mathrm{EMIM}]\left[\mathrm{GeI}_{3}\right]$, (i) $1^{\text {st }}$ (ii) $2^{\text {nd }}$ (iii) $3^{\text {rd }}$ scans. 
Scanning to positive potentials on Au electrodes (Figure 1A) we can see an anodic wave at around $+0.19 \mathrm{~V} v s . \mathrm{Ag} \mid \mathrm{LaF}_{3}$ for $[\mathrm{EMIM}] \mathrm{I}$ and around $+0.53 \mathrm{~V} v s . \mathrm{Ag} \mid \mathrm{LaF}_{3}$ for $\left[\mathrm{N}^{n} \mathrm{Bu}_{4}\right] \mathrm{I}$, which we attribute to oxidation of $\mathrm{I}^{-}$to $\mathrm{I}_{3}^{-}$as in other non-aqueous solvents. ${ }^{[30]}$ We attribute differences in potential for oxidation in the two electrolytes to the effects of ion pairing with the cation in the low dielectric solvent.

Initial studies of the voltammetry of $\left[\mathrm{GeCl}_{3}\right]^{-},\left[\mathrm{GeBr}_{3}\right]^{-}$and $\left[\mathrm{GeI}_{3}\right]^{-}$were carried out at Au electrodes, Figure 1B to D and Table 1. For all three germanium(II) halides, cyclic voltammetry shows a single reduction wave on the first cycle, which is attributed to the 2-electron reduction of the germanium from $\mathrm{Ge}^{\mathrm{II}}$ to $\mathrm{Ge}^{0}$.

$$
\left[\mathrm{GeX}_{3}\right]^{-}+2 \mathrm{e}^{-} \longrightarrow \mathrm{Ge}(0)+3 \mathrm{X}^{-} \quad(\mathrm{X}=\mathrm{Cl}, \mathrm{Br}, \mathrm{I})
$$

All three waves are of similar height, $\sim 20 \mathrm{~mA} \mathrm{~cm}{ }^{-2}$, and are noisy, consistent with mass transport limited behaviour where the noise is due to convection in the cell. ${ }^{[31]}$ This plateau current corresponds to a deposition rate of $\sim 100 \mu \mathrm{m} \mathrm{hr}^{-1}$ assuming $100 \%$ Faradaic efficiency and continues until an approximately $\sim 0.4 \mu \mathrm{m}$ thick film is formed on the electrode surface (see supporting information Figure S1 for chronoamperograms). There is no sign of a stripping peak on the return scan and subsequent cycles display predominantly capacitive charging.

Comparing the results for the three halides, it is clear that the deposition potential shifts anodic on going from chloride to bromide to iodide, so that the reduction of $\left[\mathrm{GeI}_{3}\right]^{-}$occurs at the most positive potential. Similar voltammetry was found in liquid difluoromethane (see supporting information Figure S2) and the trend here follows that found for the electrochemistry of these germanium complexes in dichloromethane. ${ }^{[25]}$ The anodic shift in the deposition potential is beneficial for 
germanium deposition since it reduces the contribution from electrolyte breakdown at the more negative potential. The trend in the reduction potentials for the three germanium halides follows that of the Ge-halide bond strength.

Table 1: Parameters for Ge deposition measured in supercritical difluoromethane

\begin{tabular}{|l|c|c|c|c|c|}
\hline Ge Precursor & $\begin{array}{c}\boldsymbol{E}_{\text {onset }} \boldsymbol{v s} . \\
\mathbf{A g} \mid \mathbf{L a F}_{\mathbf{3}} / \mathbf{V}\end{array}$ & $\begin{array}{c}\boldsymbol{E}_{\mathbf{P C} / \mathbf{2}} \boldsymbol{v s} . \\
\mathbf{A g} \mid \mathbf{L a F}_{\mathbf{3}} / \mathbf{V}\end{array}$ & $\begin{array}{c}\boldsymbol{j}_{\text {(exp) }} / \\
\mathbf{m A ~}^{-2}\end{array}$ & $\begin{array}{c}\mathbf{C h a r g e}_{\mathbf{2}} \mathbf{m C} \\
\mathbf{c m}^{-2}\end{array}$ & $\begin{array}{c}\text { Thickness } \\
/ \boldsymbol{\mu m}\end{array}$ \\
\hline$[\mathrm{EMIM}]\left[\mathrm{GeCl}_{3}\right]$ & -0.71 & -0.79 & -18.7 & 328 & 0.46 \\
\hline$[\mathrm{EMIM}]\left[\mathrm{GeBr}_{3}\right]$ & -0.28 & -0.46 & -18.8 & 279 & 0.40 \\
\hline$[\mathrm{EMIM}]\left[\mathrm{GeI}_{3}\right]$ & -0.23 & -0.40 & -20.35 & 471 & 0.67 \\
\hline
\end{tabular}

$E_{\mathrm{PC} / 2}$ is the cathodic half peak potential potential. The charge is calculated from the Faradaic response seen in the first cyclic voltammogram before passivation.

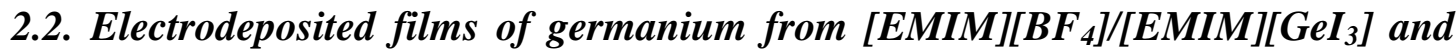
$\left[N^{n} \mathrm{Bu}_{4}\right]\left[\mathrm{BF}_{4}\right] /\left[N^{n} \mathrm{Bu}_{4}\right]\left[\mathrm{GeI}_{3}\right]$ on TiN electrodes in $\mathrm{scCH}_{2} \mathrm{~F}_{2}$

Electrodeposition of germanium from $\left[\mathrm{GeI}_{3}\right]^{-}$onto titanium nitride (TiN) electrodes was investigated. TiN is a typical barrier material used within the electronics industry and, unlike gold, does not form alloys with Ge. Two different cations were investigated, [EMIM $]^{+}$and $\left[\mathrm{N}^{n} \mathrm{Bu}_{4}\right]^{+}$. Deposition was carried out for $4000 \mathrm{~s}$ at $-1.05 \mathrm{~V}$ vs. $\mathrm{Ag} \mid \mathrm{LaF}_{3}$ in $\mathrm{scCH}_{2} \mathrm{~F}_{2}$ at $19.1 \mathrm{M} \mathrm{Pa}$ and $358 \mathrm{~K}$ from (i) $16 \mathrm{mM}$ [EMIM][GeI 3 with $60 \mathrm{mM}[\mathrm{EMIM}]\left[\mathrm{BF}_{4}\right]$ and (ii) $16 \mathrm{mM}\left[\mathrm{N}^{n} \mathrm{Bu}_{4}\right]\left[\mathrm{GeI}_{3}\right]$ with $60 \mathrm{mM}\left[\mathrm{N}^{n} \mathrm{Bu}_{4}\right]\left[\mathrm{BF}_{4}\right]$. Chronoamperograms for the two electrolytes are shown in Figure 2A. Integration of the current gives a deposition rate of $3.22 \mathrm{C} \mathrm{cm}^{-2} \mathrm{hr}^{-1}$ and $4.32 \mathrm{C} \mathrm{cm}^{-2} \mathrm{hr}^{-1}$ for the $\left[\mathrm{N}^{n} \mathrm{Bu}_{4}\right]^{+}$and $[\mathrm{EMIM}]^{+}$systems respectively, corresponding to plating rates (assuming $100 \%$ Faradaic efficiency) of $2.27 \mu \mathrm{m} \mathrm{hr}^{-1}$ and $3.04 \mu \mathrm{m} \mathrm{hr}^{-1}$ respectively. Note that both plating rates are considerably larger than that obtained previously for the equivalent chloride containing electrolyte $\left(\sim 0.4 \mu \mathrm{m} \mathrm{hr}^{-1}\right)^{[23 \mathrm{a}]}$ and comparable with deposition rates reported for ionic liquids at room temperature. ${ }^{[19 a]}$ However, the 
deposition rate is lower than that reported for deposition at elevated temperature from ionic liquid reported by $\mathrm{Wu}$ et al. ${ }^{[19 b]}$ Note that these experiments are carried out in an undivided cell and that mixing in the cell is quite efficient so there is the possibility that products of the counter electrode reaction, including $\mathrm{I}_{3}{ }^{-}$, can react at the working electrode during the extended electrodeposition.
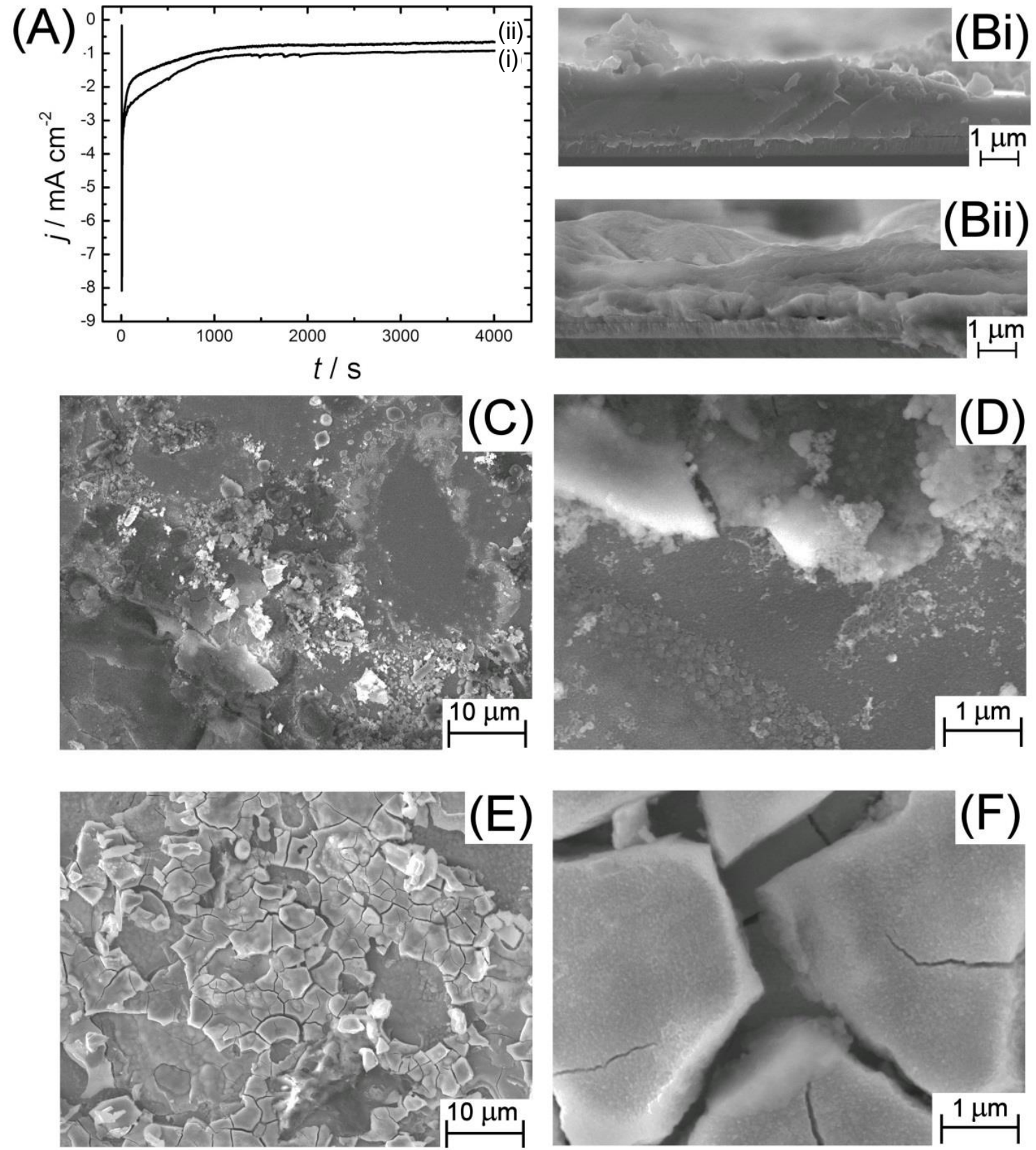

Figure 2: (A) Chronoamperogram recorded for Ge deposition from $\mathrm{scCH}_{2} \mathrm{~F}_{2}(358 \mathrm{~K}$, $19.2 \mathrm{MPa})$ at $E_{\text {dep }}=-1.05 \mathrm{~V} v s . \mathrm{Ag} \mid \mathrm{LaF}_{3}$ for $4000 \mathrm{~s}$ from a plating bath containing (i) $16 \mathrm{mM}$ [EMIM] $\left[\mathrm{GeI}_{3}\right]$ and $60 \mathrm{mM}[\mathrm{EMIM}]\left[\mathrm{BF}_{4}\right]$ or (ii) $16 \mathrm{mM}\left[\mathrm{N}^{n} \mathrm{Bu}_{4}\right]\left[\mathrm{GeI}_{3}\right]$ and 60 
$\mathrm{mM}\left[\mathrm{N}^{n} \mathrm{Bu}_{4}\right]\left[\mathrm{BF}_{4}\right]$. (B) SEM cross-sections of the as-deposited thin films from (i) the $[E M I M]^{+}$and (ii) the $\left[\mathrm{N}^{n} \mathrm{Bu}_{4}\right]^{+}$system. (C) and (D) high and low resolution images of the as-deposited film from plating bath (i), the [EMIM] $]^{+}$system. (E) and (F) high and low resolution images recorded of the as-deposited film from plating bath (ii), the $\left[\mathrm{N}^{n} \mathrm{Bu}_{4}\right]^{+}$system.

As-deposited films were analysed using SEM and EDX after Raman and XRD analysis which were recorded under an inert atmosphere. There is a clear effect of the choice of cation. For the $[\mathrm{EMIM}]^{+}$system, (i), the morphology is patchy and regions of bare TiN are visible. This could be due to poor adhesion and exfoliation of the deposit during depressurisation of the supercritical fluid. High resolution SEM reveals the presence of grains of the order of 0.1 to $1 \mu \mathrm{m}$. The cross-sectional image, Figure 2B(i), shows that the film is dense and 1 to $2 \mu \mathrm{m}$ thick, somewhat less than the thickness predicted by the total charge passed $(\sim 3 \mu \mathrm{m})$. For the $\left[\mathrm{N}^{n} \mathrm{Bu}_{4}\right]^{+}$system, Figure $2 \mathrm{~B}(\mathrm{ii})$, the films are composed of larger (2 to $5 \mu \mathrm{m}$ ) grains, but again there is evidence of delamination. Cross-sectional SEM imaging shows that this film is of similar thickness. EDX analysis of both samples (see supporting information S3 and S4) shows the presence of silicon, titanium and nitrogen from the substrate, germanium, and a number of impurities including: oxygen, iodide and fluoride. Iodide and fluoride originate from material precipitated on the surface of the electrode upon depressurisation of the supercritical fluid. Their concentrations can be reduced by either heat-treating the sample or by washing in dichloromethane (samples shown here were immersed for $1 \mathrm{~min})$. We attribute the presence of oxygen to the gradual air oxidation of the germanium films.

Grazing incidence X-ray diffraction patterns of as-deposited films produced from both systems contained only broad features around $27^{\circ}$ and $50^{\circ}$ and sharp reflections associated with the substrate and electrolyte components (Figure 3). Thermal 
annealing under argon at $700{ }^{\circ} \mathrm{C}$ without prior air exposure resulted in crystallisation of cubic germanium. The positions of the broad features in the unannealed samples appear likely to be due to the 111 and the overlapping 220/311 reflections of very small Ge nanocrystals. The feature at $\sim 27^{\circ}$ has a FWHM of $\sim 7^{\circ} 2 \theta$, and application of the Debye-Scherrer formula to this feature suggests an average crystallite size of $\sim 1.2$ $\mathrm{nm}$.

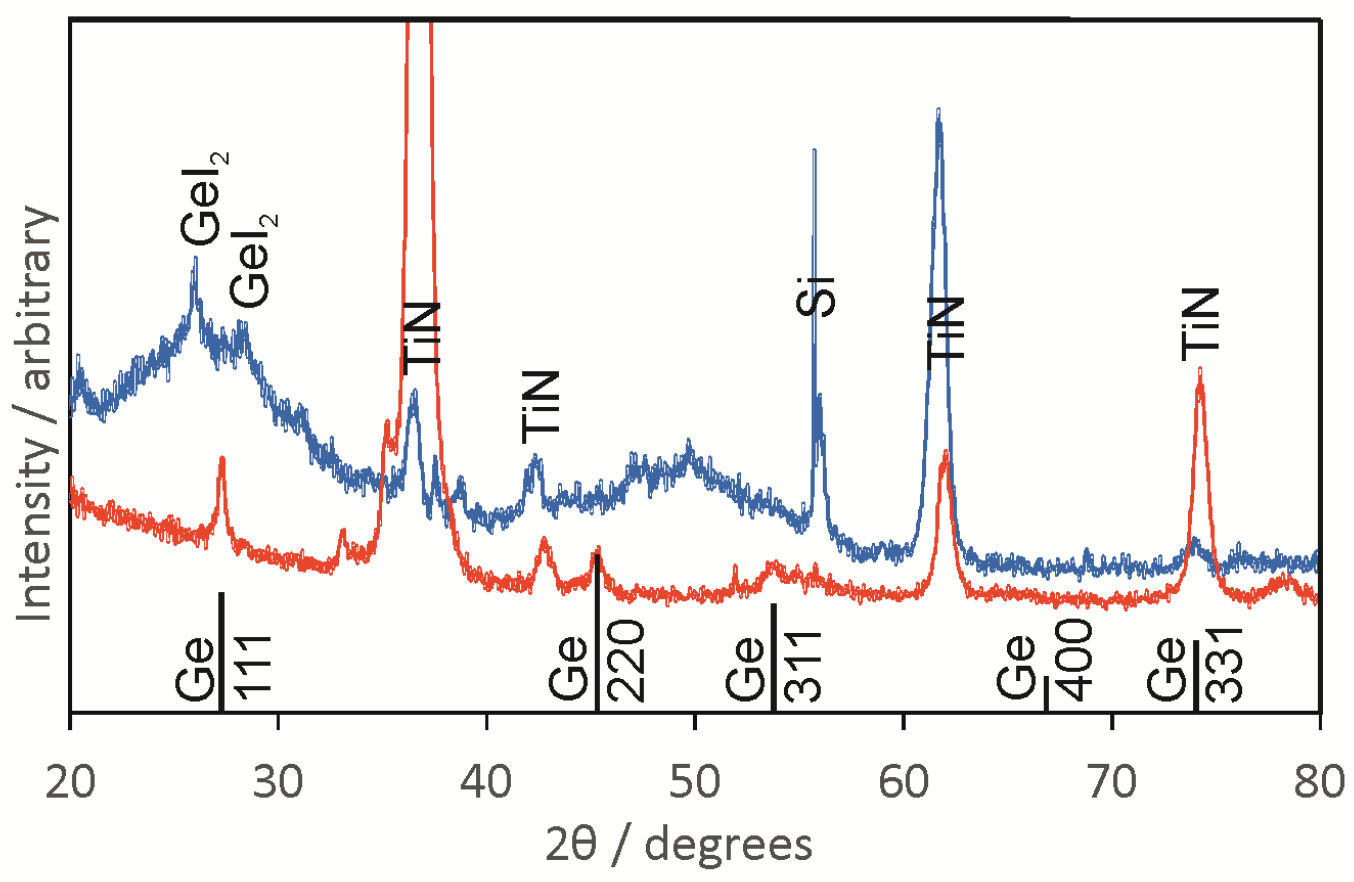

Figure 3. XRD patterns of an as-deposited Ge film (blue, top) and the same film after annealing at $700{ }^{\circ} \mathrm{C}$ in argon (red, bottom). The film was produced in $\mathrm{scCH}_{2} \mathrm{~F}_{2}$ at 358 $\mathrm{K}$ and $\sim 19.1 \mathrm{MPa}$, with $E_{\text {dep }}=-1.05 \mathrm{~V} v s . \mathrm{Ag} \mid \mathrm{LaF}_{3}$ for $4000 \mathrm{~s}$. The electrolyte composition was $16 \mathrm{mM}$ [EMIM] $\left[\mathrm{GeI}_{3}\right]$ and $60 \mathrm{mM}$ [EMIM][BF $\left.\mathrm{BF}_{4}\right]$. The stick pattern shows typical reflection positions and intensities for $\mathrm{Ge}^{[32]}$ and other phases are labelled. 

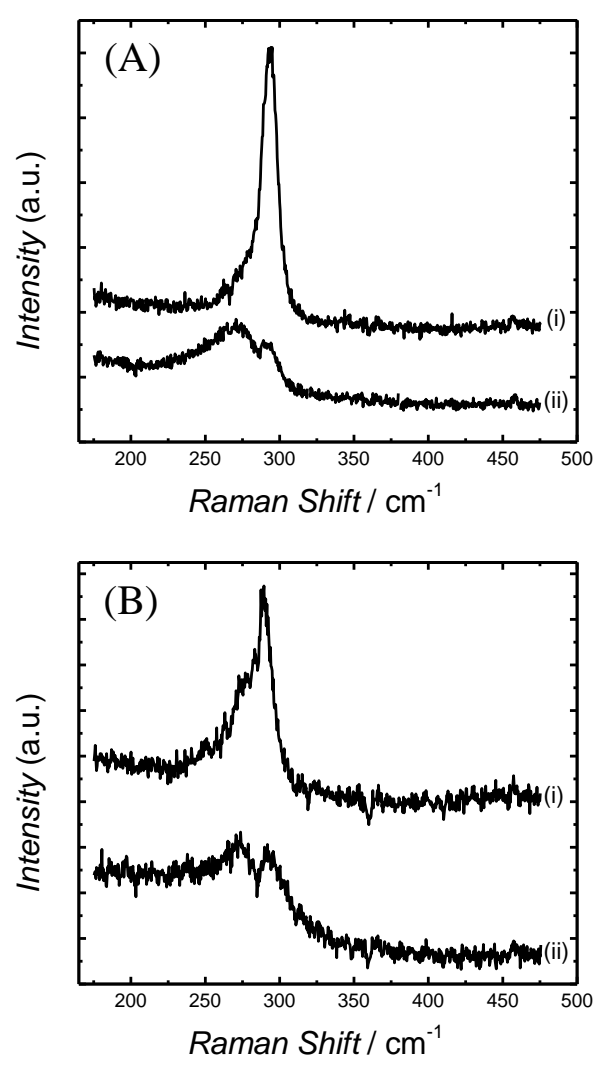

Figure 4: Representative Raman spectra recorded for the as-deposited germanium films from $\mathrm{scCH}_{2} \mathrm{~F}_{2}$ at $19.2 \mathrm{MPa}$ and $358 \mathrm{~K}, E_{\text {dep }}=-1.05 \mathrm{~V}$ vs. $\mathrm{Ag} \mid \mathrm{LaF}_{3}$ for $4000 \mathrm{~s}$. (A) Deposition from $16 \mathrm{mM}[\mathrm{EMIM}]\left[\mathrm{GeI}_{3}\right]$ and $60 \mathrm{mM}[\mathrm{EMIM}]\left[\mathrm{BF}_{4}\right]$. (B) Deposition from $16 \mathrm{mM}\left[\mathrm{N}^{n} \mathrm{Bu}_{4}\right]\left[\mathrm{GeI}_{3}\right]$ and $60 \mathrm{mM}\left[\mathrm{N}^{n} \mathrm{Bu}_{4}\right]\left[\mathrm{BF}_{4}\right]$. The spectra show protocrystalline and amorphous material, labelled (i) and (ii) respectively in the figure.

The electrodeposited Ge films were further characterised by Raman spectroscopy by mapping an area of $\sim 2 \mathrm{~mm}^{2}$ and recording $\sim 100$ spectra over a $200 \mu \mathrm{m}$ pitch square grid. Raman spectroscopy has a number of advantages for characterisation of these samples. The thickness of the deposit required is of the order of the absorption length, which at $703 \mathrm{~nm}$ is on the order $100 \mathrm{~nm} \cdot{ }^{[13 \mathrm{c}]}$ In addition, it gives characteristic spectra for both amorphous and crystalline $\mathrm{Ge}^{[23 \mathrm{~b}]}$ although it is more sensitive to crystalline material. The resultant Raman spectra can be characterised as falling into three main groups: protocrystalline, amorphous or 'unattributable'. In general, spectra were 
classified as 'unattributable' either because the sample point fell on a bare piece of the sample or because of strong background luminescence which swamped the Raman signal. Representative protocrystalline and amorphous spectra are shown in Figure 4 (the dip in the spectra at $\sim 275 \mathrm{~cm}^{-1}$ is a blemish in the CCD leading to a reduced signal that we have only been able to partially correct - see supplementary information). The amorphous spectra, Figures 4A and B (ii), are characterised by a broad hump between $250 \mathrm{~cm}^{-1}$ and $300 \mathrm{~cm}^{-1}$ centred at $280 \mathrm{~cm}^{-1}$ which is often associated with a step in the "background". ${ }^{[23 b]}$ The protocrystalline spectra however are characterised by a sharper peak at $\sim 293 \mathrm{~cm}^{-1}$ often associated/integrated with a broader feature between $250 \mathrm{~cm}^{-1}$ and $300 \mathrm{~cm}^{-1}$. These spectra are much more reminiscent of the sharp $300 \mathrm{~cm}^{-1}$ Raman peaks observed for fully crystalline cubic $\mathrm{Ge},{ }^{[23 \mathrm{~b}]}$ however the width of the protocrystalline peaks strongly suggests that the material responsible from them has a short crystal ordering length.

Table 2. Statistical analysis of the Raman spectral maps of samples produced using $\left[\right.$ EMIM] $\left[\mathrm{GeI}_{3}\right]$ and $\left[\mathrm{N}^{n} \mathrm{Bu}_{4}\right]\left[\mathrm{GeI}_{3}\right]$, using the conditions set out in Figure 4, in terms of the protocrystalline, amorphous or 'unattributable' character of the spectra.

\begin{tabular}{|c|c|c|c|}
\hline & \multicolumn{3}{|c|}{ Number of spectra of each type } \\
\hline \multicolumn{1}{|c|}{ Cation } & protocrystalline & amorphous & unattributable \\
\hline (i) $[\mathrm{EMIM}]^{+}$ & 68 & 8 & 25 \\
\hline (ii) $\left[\mathrm{N}^{n} \mathrm{Bu}_{4}\right]^{+}$ & 15 & 5 & 80 \\
\hline
\end{tabular}

To quantify the relative abundance of amorphous and protocrystalline material in our samples we have qualitatively classified each spectrum, Table 2. For the film deposited from the $[\mathrm{EMIM}]^{+}$electrolyte system (i) it is clear that the majority of the classifiable spectra are protocrystalline. In the case of the $\left[\mathrm{N}^{n} \mathrm{Bu}_{4}\right]^{+}$electrolyte system (ii) a relatively large fraction of the Raman spectra were 'unattributable', mostly due 
to broadband luminescence swamping the Raman signal, however $75 \%$ of the attributable spectra were proto-crystalline in nature. As the relative strength of Raman scattering from protocrystalline and amorphous Ge is not known, it is not possible to draw any conclusions from the Raman as to what volume fraction of the material is protocrystalline, only that protocrystalline material is wide spread across the sample. In order to investigate the nature and prevalence of the protocrystalline material, TEM bright and dark field images and selected area electron diffraction (SAED) patterns were obtained from material scraped from the film and deposited onto lacy carbon support films (Figure 5). The SAED patterns obtained (Figure 5B) clearly show both diffuse rings, consistent with amorphous Ge, and sharp spots consistent with crystalline germanium. This conclusion is supported by the radially integrated diffracted intensity plotted against the magnitude of the scattering vector shown in (Figure 5C), which has both broad humps from amorphous material, e.g. at 0.25 and $0.7 \mathrm{~nm}^{-1}$, and sharp peaks from individual crystallites on a rapidly decreasing background. Bright field images, formed using the undiffracted beam, showed uniform contrast within the flakes of film. However, dark field images, e.g. obtained by selecting a region of reciprocal space illustrated by the circle in Figure 5B, show the diffracting crystallites as isolated bright regions, typically 5-30 $\mathrm{nm}$ in size, within an amorphous matrix. Quantification of the volume fraction of nanocrystalline material proved impossible, partly because the nanocrystals were found to amorphise over time when illuminated by the electron beam.

Taken together, the Raman and electron microscopy results indicate that, unlike $\left[\mathrm{GeCl}_{3}\right]^{-}$based electrolytes, both of the $\left[\mathrm{GeI}_{3}\right]^{-}$electrolytes presented here have the capacity to produce crystalline domains within the deposit. Whilst the mechanism 
which enables this is still to be determined, it suggests that $\left[\mathrm{GeI}_{3}\right]^{-}$electrolytes may be preferable for many applications.
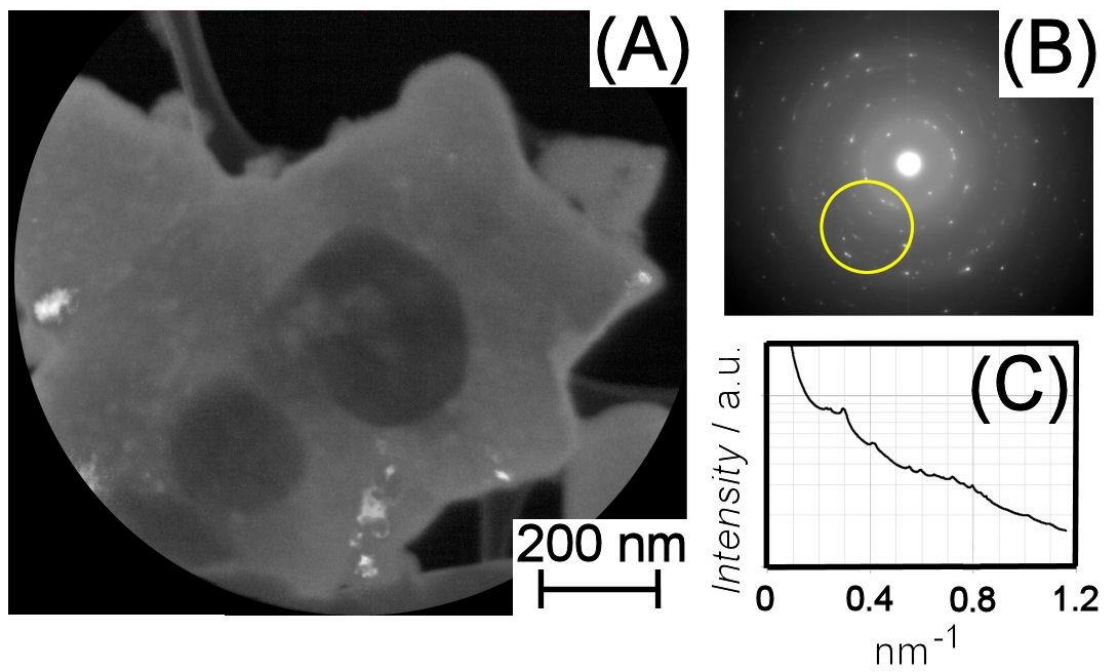

Figure 5: (A) Dark field TEM image of a portion of an as-deposited germanium film deposited at $E_{\text {dep }}=-1.05 \mathrm{~V}$ vs. $\mathrm{Ag} \mid \mathrm{LaF}_{3}$ for $4000 \mathrm{~s}$ from $\mathrm{scCH}_{2} \mathrm{~F}_{2}$ at $19.2 \mathrm{MPa}$ and 358 $\mathrm{K}$ from a plating bath containing $16 \mathrm{mM}$ [EMIM] $\left[\mathrm{GeI}_{3}\right]$ and $60 \mathrm{mM}$ [EMIM][BF 4 . (B) Corresponding selected area diffraction pattern, with the position and size of the objective aperture used to obtain (A) shown as a circle. (C) Radially integrated diffracted intensity derived from (B), showing broad features corresponding to amorphous structure $\left(0.2-0.35 \mathrm{~nm}^{-1}, 0.55-0.9 \mathrm{~nm}^{-1}\right)$ and small peaks corresponding to individual spots.

\section{Conclusions}

We have reported the first results for the study of the electrochemistry of the germanium(II) tri-halide anions, $\left[\mathrm{GeCl}_{3}\right]^{-},\left[\mathrm{GeBr}_{3}\right]^{-}$and $\left[\mathrm{GeI}_{3}\right]^{-}$, in supercritical difluoromethane at $358 \mathrm{~K}$ and $19.1 \mathrm{MPa}$. On the first scan the voltammetry shows mass transport limited currents for the reduction to germanium, but with no evidence for germanium stripping on the return scan. On the second and subsequent scans at 
gold the electrode passivates with the deposition of around $\sim 0.4 \mu \mathrm{m}$ of material in total.

The redox potentials for the onset of reduction of the three tri-halides follow the trend for the $\mathrm{Ge}-\mathrm{X}$ bond strength; $\left[\mathrm{GeCl}_{3}\right]^{-}-0.71 \mathrm{~V},\left[\mathrm{GeBr}_{3}\right]^{-}-0.28 \mathrm{~V},\left[\mathrm{GeI}_{3}\right]^{-}-0.23 \mathrm{~V}$ (all vs. $\left.\mathrm{Ag} \mid \mathrm{LaF}_{3}\right)$ with the iodide being the most easily reduced. This trend is consistent with earlier studies of these complexes in liquid dichloromethane. ${ }^{\text {[23a] }}$

Electrodeposition of germanium was carried out from supercritical difluoromethane at 19.1 $\mathrm{MPa}$ at $358 \mathrm{~K}$ containing either $16 \mathrm{mM}$ [EMIM] $\left[\mathrm{GeI}_{3}\right]$ with $60 \mathrm{mM}$ [EMIM] $\left[\mathrm{BF}_{4}\right]$ or $16 \mathrm{mM}\left[\mathrm{N}^{n} \mathrm{Bu}_{4}\right]\left[\mathrm{GeI}_{3}\right]$ with $60 \mathrm{mM}\left[\mathrm{N}^{n} \mathrm{Bu}_{4}\right]\left[\mathrm{BF}_{4}\right]$. In both cases deposition using the $\left[\mathrm{GeI}_{3}\right]^{-}$anion was around 10 times faster than that previously reported ${ }^{[23 a]}$ using $\left[\mathrm{GeCl}_{3}\right]^{-}$and deposition rates of 2 to $3 \mu \mathrm{m} \mathrm{h}^{-1}$ were achieved.

Raman spectroscopy and transmission electron microscopy showed that the resulting germanium films were protocrystalline, containing nanocrystals of germanium embedded in an amorphous germanium matrix. Heating to $700{ }^{\circ} \mathrm{C}$ in argon resulted in bulk crystallisation.

\section{Experimental Section}

\section{Chemical Reagents}

Tetrabutylammonium tetrafluoroborate $\left(\left[\mathrm{N}^{n} \mathrm{Bu}_{4}\right]\left[\mathrm{BF}_{4}\right],>99.99 \%\right)$ was purchased from Sigma Aldrich and dried for $3 \mathrm{~h}$ at $100{ }^{\circ} \mathrm{C}$ under vacuum. 1-Ethyl-3-methyl imidazolium tetrafluoroborate $\left([\mathrm{EMIM}]\left[\mathrm{BF}_{4}\right],>99.99 \%\right)$ was purchased from Iolitec $\mathrm{GmbH}$ (Germany). Difluoromethane ( $\mathrm{R} 32, \mathrm{CH}_{2} \mathrm{~F}_{2}$, Apollo, $\left.99.9 \%\right)$ was used as the supercritical fluid for electrochemical experiments and $\mathrm{CO}_{2}(\mathrm{BOC}$, supercritical fluid grade $99.999 \%$ ) was used for cleaning and purging the system of oxygen and water 
before and after experiments. The electrolytes [EMIM] $\left[\mathrm{GeCl}_{3}\right],[\mathrm{EMIM}]\left[\mathrm{GeBr}_{3}\right]$ and $[$ EMIM $]\left[\mathrm{GeI}_{3}\right]$ was prepared as discussed previously. ${ }^{[25]}$ Electrolyte $\left[\mathrm{N}^{n} \mathrm{Bu}_{4}\right]\left[\mathrm{GeI}_{3}\right]$ was prepared via a modification of this route.

\section{Apparatus}

A detailed description of the supercritical rig and electrochemical cell has been given elsewhere. ${ }^{[23 \mathrm{a}]}$ Briefly, the electrochemical cell has an internal volume of $8.5 \mathrm{~mL}$ into which 5 electrodes can be inserted. Working electrodes used throughout this work were either Au disc electrodes $(\phi=0.5 \mathrm{~mm})$ or $\sim 450 \mathrm{~nm}$ thick films of TiN sputtered onto p-type (conductivity $=\sim 10 \Omega \mathrm{cm}$ ) silicon wafers. Wafers were cut to the appropriate size then fixed to a PEEK coated stainless steel tube with the use of high temperature silver epoxy (Duacol UK) to provide an electrical contact. Electrodes were insulated using a silicate based epoxy (FortaFix, UK) to ensure that only the TiN surface was in contact with the supercritical fluid. Active areas of the working electrodes were recorded prior to the experiments hence allowing the current to be normalised to current density. Typical working electrode area was $0.4 \pm 0.1 \mathrm{~cm}^{2}$. Counter electrodes were large area (ca. $2 \mathrm{~cm}^{2}$ ) Pt flags. Ag|LaF 3 reference electrodes were used throughout this work; the potential of the $\mathrm{DMFc}^{+} / \mathrm{DMFc}$ couple (where DMFc is decamethylferrocene) is $0.088 \mathrm{~V}$ vs. $\mathrm{Ag} \mid \mathrm{LaF}_{3}$ reference in $\mathrm{scCH}_{2} \mathrm{~F}_{2}$ under these conditions. Full details of the $\mathrm{Ag} \mid \mathrm{LaF}_{3}$ reference electrodes for use in $\mathrm{scCH}_{2} \mathrm{~F}_{2}$ can be found elsewhere. ${ }^{[33]}$

The supercritical electrochemical cell was dismantled and loaded into a nitrogen filled glove box (Belle Technologies Limited, UK) where it was charged with the appropriate electrolytes. The cell was sealed, removed from the glove box then fixed 
to the supercritical rig for experiments. An Autolab 302N potentiostat system (Metrohm, UK) was used in electrochemical measurements.

\section{Analysis of electrodeposited films}

Raman spectroscopy was performed using a Coherent MIRA-900 Ti:Sapphire laser source in CW mode set to $702 \mathrm{~nm}$ and filtered using a Photonetc TLS 850 laser line filter. Raman spectra were taken in a back scattering geometry using an Olympus LMPan IR 50x objective with $2 \mathrm{~mW}$ power incident upon a 1.7 micron diameter spot on the sample. Back scattered light was collected into a Princeton Instruments TriVista triple $500 \mathrm{~mm}$ spectrometer, configured in subtractive mode, using 900, 900 and 1800 lines/mm gratings in the three stages. Spectra were measured on a Princeton Instruments, deep depleted, liquid $\mathrm{N}_{2}$ cooled silicon $\mathrm{CCD}$. We found no evidence of laser annealing of the samples reported on in this paper at any laser power up to 20 mW. On other electrodeposited Ge samples we have observed laser annealing however never at laser powers less than $10 \mathrm{~mW}$. SEM was performed on a Jeol JSM 6500F field emission scanning electron microscope. EDX spectra were recorded over $60 \mathrm{~s}$ with an accelerating voltage of $10 \mathrm{kV}$. Specimens for TEM were prepared by scraping flakes of the deposited film onto a lacy carbon support on a $\mathrm{Cu}$ mesh grid. They were examined using a JEOL $2100 \mathrm{LaB}_{6}$ TEM operating at $200 \mathrm{kV}$.

\section{XRD analysis of electrodeposited films}

X-ray diffraction (XRD) patterns were collected on a Rigaku Smartlab X-ray diffractometer $(\mathrm{Cu} \mathrm{K}, 1.5418 \AA$ A $)$ with parallel beam and a DTex250 1D detector. Grazing incidence scans were collected with a $2 \theta$ range of $10-80^{\circ}$ using a $1^{\circ}$ incident angle and a $0.1 \mathrm{~mm}$ thick X-ray line. All sample handling was anaerobic by loading a sealed sample cell with a hemicylindrical Kapton window in the glove box. Ge films 
were annealed by heating under static argon at $700{ }^{\circ} \mathrm{C}$, with anaerobic handling of films before and after the annealing process. The conditions emulate those used previously to anneal amorphous Ge films. ${ }^{[23 a]}$

\section{Acknowledgements}

The authors wish to thank the EPSRC for supporting the SCFED project through a Programme Grant (EP/I033394/1) and for providing the X-ray diffractometer through $\mathrm{EP} / \mathrm{K} 00509 \mathrm{X} / 1$ and EP/K009877/1. The SCFED project (www.scfed.net) is a multidisciplinary collaboration of British universities investigating the fundamental and applied aspects of supercritical fluids. P.N.B. gratefully acknowledges receipt of a Wolfson Research Merit Award.

\section{References}

[1] D. A. Guilhot, G. D. Emmerson, C. B. E. Gawith, S. P. Watts, D. P. Shepherd, R. B. Williams, P. G. R. Smith, Optics Lett. 2004, 29, 947-949.

[2] S. Gupta, M. L. Lee, D. M. Isaacson, E. A. Fitzgerald, Mat. Sci. Eng. B-Solid 2005, 124, 102-106.

[3] C. K. Chan, X. F. Zhang, Y. Cui, Nano Lett. 2008, 8, 307-309.

[4] R. R. King, D. Bhusari, D. Larrabee, X. Q. Liu, E. Rehder, K. Edmondson, H. Cotal, R. K. Jones, J. H. Ermer, C. M. Fetzer, D. C. Law, N. H. Karam, Prog. Photovoltaics 2012, 20, 801-815.

[5] W. Brattain, C. Garrett, The Bell Sys. Tech. J. 1955, 34, 129-134.

[6] M. Arif, M. Rahman, W. Y. San, Int. J. Adv. Manf. Tech. 2012, 63, 481-504.

[7] aY. H. Kil, H. D. Yang, J. H. Yang, A. H. Park, S. Kang, T. S. Jeong, T. S. Kim, K. H. Shim, Mat. Sci. Semicon. Proc. 2013, 16, 1405-1409; bA. M. Morales, C. M. Lieber, Science 1998, 279, 208-211.

[8] Y. B. Bolkhovityanov, A. K. Gutakovskii, A. S. Deryabin, L. V. Sokolov, Phys. Solid State 2014, 56, 247-253.

[9] aC. Fink, V. Dorkas, J. Electrochem. Soc. 1949, 95, 80-97; bG. Szekely, J. Electrochem. Soc. 1951, 98, 318-324.

[10] G. Szekely, J. Electrochem. Soc. 1951, 98, 318.

[11] aQ. Huang, S. W. Bedell, K. L. Saenger, M. Copel, H. Deligianni, L. T. Romankiw, Electrochem. Solid. State Lett. 2007, 10, D124-D126; bM. Miyagi, Y. Shimada, A. Hongo, S. Nishida, Trans. IEICE, C 1986, J69C, 1159-1165; cM. Miyagi, Y. Shimada, A. Hongo, K. Sakamoto, S. Nishida, J. Appl. Phys. 1986, 60, 454-456; dM. Miyagi, Y. Shimada, S. Nishida, Opt. Laser Technol. 1985, 17, 197-200; eW. Paatsch, J. Electrochem. Soc. 1977, 
124, 1505; fT. Papa, D. Sette, L. Stagni, J. Phys. D-Appl. Phys. 1974, 7, 20242030; gM. Saitou, K. Sakae, W. Oshikawa, Surf. Coat. Tech. 2003, 162, 101105; hQ. Huang, H. Deligianni, L. T. Romankiw, Electrochem. and Solid State Lett. 2007, 10, D121.

[12] aN. Chandrasekharan, S. C. Sevov, J. Electrochem. Soc. 2010, 157, C419C423; bN. Chandrasekharan, S. C. Sevov, J. Electrochem. Soc. 2010, 157, C140-C145.

[13] aA. I. Carim, J. S. Gu, S. Maldonado, ACS Nano 2011, 5, 1818-1830; bX. H. Liang, Y. G. Kim, D. K. Gebergziabiher, J. L. Stickney, Langmuir 2010, 26, 2877-2884; cX. H. Liang, Q. Zhang, M. D. Lay, J. L. Stickney, J. Am. Chem. Soc. 2011, 133, 8199-8204.

[14] F. Endres, C. Schrodt, Phys. Chem. Chem. Phys. 2000, 2, 5517-5520.

[15] aF. Endres, Phys. Chem. Chem. Phys. 2001, 3, 3165-3174; bF. Endres, Electrochem. Solid. State Lett. 2002, 5, C38-C40; cF. Endres, in Molten Salts XIII (Eds.: P. C. Trulove, H. C. DeLong, R. A. Mantz, G. R. Stafford, M. Matsunaga), 2002, pp. 677-689; dF. Endres, S. Z. El Abedin, Chem. Commun. 2002, 892-893; eF. Endres, S. Z. El Abedin, Phys. Chem. Chem. Phys. 2002, 4, 1640-1648; fF. Endres, S. Z. El Abedin, Phys. Chem. Chem. Phys. 2002, 4, 1649-1657; gW. Freyland, C. A. Zell, S. Z. El Abedin, F. Endres, Electrochim. Acta 2003, 48, 3053-3061.

[16] aA. A. Aal, R. Al-Salman, M. Al-Zoubi, N. Borissenko, F. Endres, O. Hoefft, A. Prowald, S. Z. El Abedin, Electrochim. Acta 2011, 56, 10295-10305; bR. Al-Salman, S. Z. El Abedin, F. Endres, Phys. Chem. Chem. Phys. 2008, 10, 4650-4657; cR. Al-Salman, F. Endres, J. Mater. Chem. 2009, 19, 7228-7231; dR. Al-Salman, J. Mallet, M. Molinari, P. Fricoteaux, F. Martineau, M. Troyon, S. Z. El Abedin, F. Endres, Phys. Chem. Chem. Phys. 2008, 10, 62336237; eR. Al-Salman, X. Meng, J. Zhao, Y. Li, U. Kynast, M. M. Lezhnina, F. Endres, Pure Appl. Chem. 2010, 82, 1673-1689; fS. Z. El Abedin, F. Endres, Chemphyschem 2006, 7, 58-61; gF. Endres, Zeit. Phys. Chem. 2004, 218, 255283; hF. Endres, MRS Bulletin 2013, 38, 567-571; iA. Lahiri, S. Z. El Abedin, F. Endres, J. Phys. Chem. C 2012, 116, 17739-17745; jA. Lahiri, M. Olschewski, O. Hoefft, S. Z. El Abedin, F. Endres, J. Phys. Chem. C 2013, 117, 1722-1727; kX. Meng, R. Al-Salman, J. Zhao, N. Borissenko, Y. Li, F. Endres, Angew. Chem. Int. Edn. 2009, 48, 2703-2707; 1X. Meng, X. Liu, J. Zhao, W. Xin, Y. Li, Prog. Chem. 2010, 22, 277-283.

[17] aX. Meng, J. Zhao, H. Li, F. Endres, Y. Li, Optics Express 2012, 20, 94219430; bM. Xiangdong, R. Al-Salman, Z. Jiupeng, N. Borissenko, L. Yao, F. Endres, Angew.Chem. Int. Edn. 2009, 48, 2703-2707.

[18] aI. Mukhopadhyay, W. Freyland, Chem. Phys. Lett. 2003, 377, 223-228; bM. Wu, N. R. Brooks, S. Schaltin, K. Binnemans, J. Fransaer, Phys. Chem. Chem. Phys. 2013, 15, 4955-4964.

[19] aM. X. Wu, N. R. Brooks, S. Schaltin, K. Binnemans, J. Fransaer, Phys. Chem. Chem. Phys. 2013, 15, 4955-4964; bM. X. Wu, G. Vanhoutte, N. R. Brooks, K. Binnemans, J. Fransaer, Phys. Chem. Chem. Phys. 2015, 17, 12080-12089.

[20] aA. I. Carim, S. M. Collins, J. M. Foley, S. Maldonado, J. Am. Chem. Soc. 2011, 133, 13292-13295; bJ. S. Gu, S. M. Collins, A. I. Carim, X. G. Hao, B. M. Bartlett, S. Maldonado, Nano Lett. 2012, 12, 4617-4623; cE. Fahrenkrug, J. S. Gu, S. Jeon, P. A. Veneman, R. S. Goldman, S. Maldonado, Nano Lett. 
2014, 14, 847-852; dL. Y. Ma, J. S. Gu, E. Fahrenkrug, S. Maldonado, J. Electrochem. Soc. 2014, 161, D3044-D3050.

[21] R. S. Wagner, W. C. Ellis, Appl. Phys. Lett. 1964, 4, 89.

[22] N. K. Mahenderkar, Y. C. Liu, J. A. Koza, J. A. Switzer, ACS Nano 2014, 8, 9524-9530.

[23] aC. Y. Cummings, P. N. Bartlett, D. Pugh, G. Reid, W. Levason, M. M. Hasan, A. L. Hector, J. Spencer, D. C. Smith, J. Electrochem. Soc 2015, 162, D619-D624; bJ. Ke, P. N. Bartlett, D. Cook, T. L. Easun, M. W. George, W. Levason, G. Reid, D. Smith, W. T. Su, W. J. Zhang, Phys. Chem. Chem. Phys. 2012, 14, 1517-1528.

[24] P. N. Bartlett, D. A. Cook, A. L. Hector, W. Levason, G. Reid, W. Zhang, M. W. George, J. Ke, D. C. Smith, Phys. Chem. Chem. Phys. 2014, 16, 92029219.

[25] P. N. Bartlett, C. Y. Cummings, W. Levason, D. Pugh, G. Reid, Chem. Eur. J. 2014, 20, 5019-5027.

[26] J. M. Pearce, N. Podraza, R. W. Collins, M. M. Al-Jassim, K. M. Jones, J. Deng, C. R. Wronski, Appl. Phys. Lett. 2007, 101, 114301

[27] P. N. Bartlett, D. C. Cook, M. W. George, J. Ke, W. Levason, G. Reid, W. T. Su, W. J. Zhang, Phys. Chem. Chem. Phys. 2011, 13, 190-198.

[28] J. Newman, J. Electrochem. Soc. 1966, 113, 501-502.

[29] A. M. Navarro-Suarez, J. C. Hidalgo-Acosta, L. Fadini, J. M. Feliu, M. F. Suarez-Herrera, J. Phys. Chem. C 2011, 115, 11147-11155.

[30] I. M. Kolthoff, J. F. Coetzee, J. Am. Chem. Soc. 1957, 79, 1852-1858.

[31] J. A. Branch, D. A. Cook, P. N. Bartlett, Phys. Chem. Chem. Phys. 2015, 17, 261-267.

[32] A. S. Cooper, Acta Crystall. 1962, 15, 578-582.

[33] C. Y. Cummings, J. A. Branch, P. W. Richardson, P. N. Bartlett, Electrochim. Acta, in press. 